\title{
Erratum to: Land Use and Occupation of Coastal Tropical Wetlands: Whale Coast, Bahia, Brazil
}

\author{
Sirius O. Souza, Cláudia C. Vale, and Regina C. Oliveira
}

\section{Erratum to:}

Chapter 5 in: C.W. Finkl, C. Makowski (eds.), Coastal Wetlands: Alteration and Remediation, Coastal Research Library 21, https://doi.org/10.1007/978-3-319-56179-0_5

In chapter 5 titled 'Land Use and Occupation of Coastal Tropical Wetlands: Whale Coast, Bahia, Brazil", the first name of the second co-author was presented as "Câmara" C. Vale, by oversight. The correct first name is "Cláudia" and the name has been updated as Cláudia C. Vale in the chapter header and opener, Table of Contents, and Contributors list.

Figure 5.15 on page 178 has been cut off at the bottom and it has been repositioned. 